\title{
ANALISIS KEBUTUHAN TERHADAP BAHAN AJAR GAME BASED LEARNING TERINTEGRASI KARAKTER KREATIF
}

\author{
Ika Febriana Wati, Yuniawatika, dan Sri Murdiyah \\ Universitas Negeri Malang \\ email: ika.febriana.1601516@students.um.ac.id
}

\begin{abstract}
Abstrak: Pendidikan merupakan sarana pembentuk kepribadian bangsa. Pendidikan dapat menjadi sarana utama sebagai penguatan karakter bangsa. Dalam implementasinya pada kurikulum 2013, pengembangan bahan ajar menjadi salah satu kunci utama yang dapat diintegrasikan dengan penguatan karakter. Tujuan penelitian ini adalah memperoleh informasi mengenai analisis kebutuhan tentang: (1) kebutuhan bahan ajar berbasis game based learning pada pembelajaran di kelas V SDN Bendogerit 2 Kota Blitar; (2) muatan pembelajaran yang memerlukan bahan ajar; (3) jenis bahan ajar yang dibutuhkan; (4) penguatan karakter yang terintegrasi dalam bahan ajar; dan (5) elemen yang terkandung di dalam bahan ajar tersebut. Subjek dari penelitian ini terdiri atas guru dan siswa kelas V SDN Bendogerit 2 Kota Blitar. Pengumpulan data dilakukan melalui Teknik wawancara, angket, dan observasi. Hasil angket analisis kebutuhan yang diisi oleh siswa menunjukkan bahwa rata-rata kebutuhan bahan ajar mencapai persentase 83,12\%, dengan 2 di antara rinciannya adalah 85,6\% setuju dengan adanya bahan ajar yang berbasis game based learning dan $75,9 \%$ setuju adanya penguatan karakter kreatif pada bahan ajar. Berdasarkan hasil tersebut, dapat disimpulkan bahwa diperlukan pengembangan secara berkelanjutan berupa bahan ajar berbasis game based learning yang terintegrasi karakter kreatif untuk tema ekosistem di kelas V SDN Bendogerit 2 Kota Blitar.
\end{abstract}

Kata Kunci: analisis kebutuhan, bahan ajar, game based learning, karakter kreatif

\section{NEED ANALYSIS OF GAME BASED LEARNING TEACHING MATERIALS THAT INTEGRATED WITH CREATIVE CHARACTER}

\begin{abstract}
Education is a means of forming the nation personality. Education can be the main means of strengthening the nation character. In its implementation in the 2013 curriculum, the development of teaching materials is one of the main keys that can be integrated with character strengthening. This study aims to obtain information on the needs analysis of: (1) the need for game based learning teaching materials in fifth grade of SDN Bendogerit 2 Blitar; (2) the content of the teaching materials; (3) the types of the teaching materials; (4) reinforcement of characters that are integrated in teaching materials; and (5) elements contained in these teaching materials. This study subjects were teachers and fifth grade students. Data collection techniques carried out through interviews, questionnaires, and observations. The results of the needs analysis questionnaire filled out by students showed that the average need reached a percentage of $83.12 \%$, with 2 of the details being $85.6 \%$ agreeing with game based learning and $75.9 \%$ agreeing to strengthen creative character in teaching materials. Based on these results, it can be concluded that development of game based learning teaching materials that integrates creative characters for ecosystem theme in class V SDN Bendogerit 2 Blitar is needed.
\end{abstract}

Keywords: needs analysis, teaching materials, game based learning, creative character

\section{PENDAHULUAN}

Pendidikan merupakan sarana utama pembentuk kepribadian bangsa. Berdasarkan Permendikbud No. 22 Tahun 2016 tentang Standar Proses Pendidikan Dasar dan Menengah bahwa pembelajaran hendaknya berlangsung dengan interaktif, inspiratif, menyenangkan, menantang, efisien, dan memotivasi siswa untuk berperan aktif. Standar proses ini biasa dikenal dengan istilah Pembelajaran Aktif, Inovatif, Kreatif, dan Menyenangkan (PAIKEM). Dari aturan tersebut, terdapat pesan yang tersirat bahwa pendidikan harus mampu menunjang selu- 
ruh perkembangan potensi siswa dari segala aspek. Siswa harus dapat difasilitasi dengan maksimal agar dapat mengembangkan pengetahuan, sikap, dan keterampilannya.

Penekanan diterapkannya standar proses PAIKEM salah satunya untuk mengembangkan karakter siswa. Karakter merupakan sikap nyata yang semestinya dilakukan ketika sedang berhadapan dengan orang lain (Rahayuningtyas \& Mustadi, 2018). Salah satu tujuan pendidikan yang berhubungan dengan karakter ialah pendidikan harus mampu menanamkan karakter yang nilai-nilainya dapat melekat dalam hati nurani sehingga menjadi suatu kepribadian yang baikdalam kehidupan sehari-hari (Davidson, 2014). Pengintegrasian pendidikan karakter pada setiap pelajaran menjadi sangat penting demi kesiapan siswa dalam menghadapi setiap permasalahan dalam kehidupannya (Qodriyah \& Wangid, 2015).

Penekanan pendidikan karakter dalam implementasinya di bidang pendidikan juga diatur oleh pemerintah. Berdasarkan Permendikbud No. 20 Tahun 2018 tentang Penguatan Pendidikan Karakter pada Satuan Pendidikan Formal yang menyatakan bahwa pendidikan di tingkat sekolah dasar (SD) memiliki muatan karakter yang lebih besar dari pendidikan menengah. Menurut Putri (2011) upaya penguatan karakter tersebut diwujudkan dalam 18 nilai karakter. Nilai-nilai karakter tersebut, yaitu: (1) religius; (2) jujur; (3) toleransi; (4) disiplin; (5) kerja keras; (6) kreatif; (7) mandiri; (8) demokratis; (9) rasa ingin tahu; (10) semangat kebangsaan; (11) cinta tanah air; (12) menghargai preatasi; (13) bersahabat atau komunikatif; (14) cinta damai; (15) gemar membaca; (16) peduli lingkungan; (17) peduli sosial; dan (18) tanggung jawab. Dari keseluruhan karakter tersebut tentu ada beberapa karakter yang masih belum maksimal pembudayaannya. Permasalahan tersebut menunjukkan pentingnya analisis kebutuhan terhadap fokus penguatan karakter yang harus dikembangkan di suatu sekolah dasar (SD) termasuk di SDN Bendogerit 2 Kota Blitar.

Upaya penerapan PAIKEM yang mengintegrasikan penguatan karakter sedang digencarkan di kelas V SDN Bendogerit 2 Kota Blitar. Upaya ini dapat dilakukan melalui pemilihan pengembangan bahan ajar yang akan digunakan dengan tepat. Menurut Nugraha, Binadja, \& Supartono (2013:28), bahan ajar merupakan semua jenis bahan yang digunakan untuk membantu guru dalam melaksanakan kegiatan pembelajaran di kelas. Paparan pengertian bahan ajar tersebut menunjukkan bahwa bahan ajar mampu membawa dampak yang signifikan pada proses pembelajaran. Apabila pemilihannya tidak tepat tentu dapat membawa dampak yang tidak diinginkan pada siswa.

Pengembangan bahan ajar pada penerapan Kurikulum 2013 harus memuat kajian tema tertentu dikarenakan bentuk pembelajaran yang tematik terpadu. Menurut Karitas (2017), dalam mengembangkan tiga kompetensi dasar siswa pada Kurikulum 2013 yang terdiri dari ranah pengetahuan, sikap, dan keterampilan dapat dilakukan dengan memadukan ketiga ranah tersebut melalui penerapan pembelajaran tematik terpadu. Pembelajaran yang menerapkan tematikterpadu dianggap lebih faktual dan dekat dengan kehidupan siswa. Hal ini dapat sangat membantu dalam pengintegrasian pendidikan karakter karena karakter akan lebih mudah diserap oleh siswa apabila materi-materi yang dipelajari dekat dengan kehidupannya.

Pengembangan bahan ajar yang dilakukan harus dirancang dengan sebaik mungkin. Hal ini didasarkan pada pentingnya peran bahan ajar sebagai fasilitas pe- 
nunjang pembelajaran. Keberhasilan belajar siswa sangat dipengaruhi oleh pemilihan bahan ajar. Maka dari itu, melakukan analisis kebutuhan berdasarkan pendapat siswa merupakan cara yang sangat tepat untuk memperoleh data yang valid sebelum penentukan bahan ajar yang akan dikembangkan. Selain itu, pentingnya mempung pendapat siswa dalam melakukan analisis kebutuhan didasarkan pada penyesuaian dengan karakteristik siswa. Hal ini mengingat bahwa siswa memiliki karakteristik yang berbeda-beda, utamanya dalam hal gaya belajar. Menurut Deporter \& Hernacki (Bire, Geradus, \& Bire, 2014) terdapat tiga gaya belajar siswa yaitu visual, auditorial, dan kinestetik. Siswa akan lebih berminat dengan pembelajaran yang sesuai dengan gaya belajaranya. Hasil penelitian Bintartik, Yuniawatika, \& Untari (2017: 104-105), menunjukkan bahwa gaya belajar siswa kelas V di SD Kota Blitar cukup bervariasi dan yang paling dominan adalah auditorial.

Bahan ajar yang digunakan dalam pembelajaran memiliki jenis yang beragam. Jenis-jenis bahan ajar menurut Tocharman (Nugraha, Binadja, \& Supartono, 2013) meliputi bahan ajar visual, audio, audio visual, dan interactive teaching material. Apa pun jenis bahan ajarnya, sebaiknya memuat elemen-elemen yang dibutuhkan dalam pembelajaran. Bahan ajar yang baik mencakup tujuan pembelajaran, kompetensi dasar, materi pembelajaran, ilustrasi media, prosedur pembelajaran, latihan dilengkapi dengan petunjuk jawaban, umpan balik, daftar pustaka (Hernawan, Permasih, \& Dewi, 2012).

Salah satu bentuk pilihan bahan ajar yang dapat merangkum semua jenis karakteristik siswa adalah bahan ajar bermuatan game edukasi. Games banyak disenangi oleh siswa maupun guru. Hasil analisis kebutuhan yang dilakukan oleh Waldopo (2011: 252) menunjukkan hasil bahwa format yang paling disenangi siswa dan guru dalam media pembelajarannya adalah games dan tutorial.

Game edukasi dapat diterapkan dengan model game-based learning. Berdasarkan pendapat Daeng (Ismail, 2009:17) bermain merupakan kegiatan yang dilakukan dalam setiap kehidupan anak dan menjadi bagian integral dari proses penguatan kepribadiannya. Dengan demikian, game based learning dapat lebih dihayati oleh siswa sekaligus sebagai upaya pembentukan karakter pada siswa.

Implementasi game based learning pada bahan ajar yang digunakan siswa dapat menjadi solusi inovatif untuk menyelesaikan berbagai permasalahan pembelajaran. Menurut Maulidina, Susilaningsih, \& Abidin (2018:114) game based learning adalah jenis serious game yang dirancang untuk tujuan tertentu dalam pembelajaran. Bahan ajar game based learning menurut Blessinger dan Wankel (Hidayat, 2018) harus memenuhi karakteristik antara lain ada tantangan dan penyesuaian, ada tujuan yang diraih, memerlukan keahlian sosial dan kerja sama, menarik dan menggembirakan, adanya assesment, interaktif, adanya umpan balik, dan adanya keterampilan pemecahan masalah.

Pemilihan bahan ajar berbasis game based learning didukung pula dengan keberhasilan berbagai penelitian terdahulu. Berdasarkan penelitian Ratminingsih (2018) diketahui bahwa dalam pembelajaran yang memanfaatkan games dapat membuat siswa semangat berpartisipasi aktif dan tertantang untuk mampu memahami apa yang dijelaskan oleh guru agar dapat memecahkan dalam games. Selain itu, penggunaan games dan motivasi belajar siswa memiliki hubungan positif dan signifikan. Penelitian ini menekankan permainan yang memanfaatkan sejumlah media permainan terutama 
board games (Wang, Shang, \& Briody, 2011). Apabila media permainan ini dikolaborasikan dengan buku yang berisi elemen-elemen khusus berdasarkan kelabutuhan guru dan siswa kelas V SDN Bendogerit 2 Kota Blitar, tentu bahan ajar akan semakin menunjang pembelajaran dengan optimal.

Berdasarkan latar belakang dan kajian teori di atas penelitian ini dilakukan untuk mendapatkan data dan informasi serta analisis tentang: (1) kebutuhan bahan ajar berbasis game based learning pada pembelajaran di kelas V SDN Bendogerit 2 Kota Blitar; (2) muatan pembelajaran yang memerlukan bahan ajar; (3) jenis bahan ajar yang dibutuhkan; (4) penguatan karakter yang terintegrasi dalam bahan ajar; dan (5) elemen yang terkandung di dalam bahan ajar tersebut. Penelitian ini diharapkan menjadi acuan dalam memperoleh data hasil analisis kebutuhan bahan ajar di kelas V SDN Bendogerit 2 Kota Blitar.

\section{METODE}

Rancangan penelitian yang digunakan adalah penelitian deskriptif kuantitatif. Subjek penelitiannya yaitu guru dan siswa kelas V SDN Bendogerit 2 Kota Blitar. Penelitian dilaksanakan pada bulan Desember 2019 hingga Januari 2020. Pengumpulan data dilakukan melalui teknik angket, wawancara, dan observasi.

Tahapan penelitian pertama yang dilakukan yaitu melakukan wawancara. Nara sumbernya adalah guru kelas $\mathrm{V}$ yaitu $\mathrm{Ibu}$ Lina Krisnawati, S.Pd.SD. Topik dari wawancara meliputi tiga topik yaitu bahan ajar, karakteristik siswa, dan kurikulum. Topik bahan ajar meliputi pertanyaan ketersediaan bahan ajar, intensitas penggunaan bahan ajar, dan permasalahan yang sering muncul beserta harapnnya. Topik karakteristik siswa meliputi pertanyaan seputar jumlah keseluruhan siswa kelas $\mathrm{V}$, hasil belajar siswa, mo- tivasi belajarnya, permasalahan yang sering muncul, dan karakter yang perlu ditingkatkan. Pada topik kurikulum yang digunakan terdapat pertanyaan-pertanyaan mengenai kurikulum yang diterapkan, metode pembelajaran yang sering diterapkan, permasalahan mengenai kurikulum, dan tema yang membutuhkan pengembangan bahan ajar.

Kegiatan observasi dilaksanakan pada saat pelaksanaan pembelajaran tematik. Tujuan dari observasi untuk memperoleh data asli di lapangan dari sudut pandang selain guru dan siswa. Tahap selanjutnya yaitu pengisian angket analisis kebutuhan oleh siswa kelas V. Tujuan pengisisan ngket ini untuk mengetahui pendapat siswa mengenai bahan ajar yang siswa butuhkan. Topik pada angket ini meliputi muatan yang membutuhkan bahan ajar, jenis bahan ajar yang dibutuhkan, muatan karakter pada bahan ajar, dan elemen yang dibutuhkan pada bahan ajar.

Angket analisis kebutuhan menggunakan skala Guttman yang termasuk skala scalogram yang sangat baik untuk meyakinkan hasil penelitian. Jawaban dari siswa "ya" bernilai " 1 " dan "tidak" bernilai " 0 ", untuk alternatif jawaban dalam angket. Penelitian ini berbentuk cheklist dalam menggunankan skala Guttman. Selanjutnya hasilnya dianalisis secara kuantitatif dalam bentuk persentase. Berikut rumus penghitungan persentase data analisis kebutuhan.

$$
P=\frac{f}{n} \times 100 \%
$$

Keterangan:

$\mathrm{P}=$ Persentase

$f=$ Frekuensi jawaban

$P=100$

$n=$ Jumlah jawaban

Kategori untuk mengiterpretasikan hasil persentase analisis kebutuhan diperoleh dari modifikasi hasil penelitian Munggaran (2012). Kategori ini dipaparkan pada Tabel1. 
Tabel 1. Kategori Persentase

\begin{tabular}{cl}
\hline Persentase & \multicolumn{1}{c}{ Kategori } \\
\hline $0-1,9 \%$ & Tidak dibutuhkan \\
$2 \%-25,9 \%$ & Sebagian kecil membutuhkan \\
$26 \%-49,9 \%$ & Kurang dari setengahnya membutuhkan \\
$50 \%$ & Setengahnya membutuhkan \\
$50,1 \%-75,9 \%$ & Lebih dari setengahnya membutuhkan \\
$76 \%-99,9 \%$ & Sebagian besar membutuhkan \\
$100 \%$ & Seluruhnya membutuhkan \\
\hline
\end{tabular}

Hasil secara kuantitatif hasil pengisian angket diinterpretasikan sesuai dengan Tabel 1. Apabila hasil menunjukkan persentase lebih dari sama dengan 50\%, maka dapat disimpulkan bahwa bahan ajar dibutuhkan. Apabila kurang dari 50\%, maka menunjukkan bahwa pengembangan bahan ajar tidak dibutuhkan. Hasil dalam bentuk deskriptif memaparkan keseluruhan hasil tahapan analisis kegiatan. Data ini berupa deskripsi hasil interpretasi angket, hasil saran, dan komentar yang dicantumkan oleh siswa pada angket, hasil wawancara dengan guru kelas, dan hasil observasi.

\section{HASIL DAN PEMBAHASAN Hasil}

Hasil wawancara dengan guru kelas V yakni Ibu Lina Krisnawati, S.Pd.SD. terkait kebutuhan bahan ajar pada pembelajaran di kelas V SDN Bendogerit 2 Kota Blitar dibagi menjadi tiga topik. Topik dari wawancara meliputi bahan ajar, karakteristik siswa, dan kurikulum yang digunakan. Hasil wawancara mengenai topik bahan ajar dipaparkan pada Tabel 2. Hasil wawancara mengenai karakteristik siswa dipaparkan pada Tabel 3. Hasil wawancara tentang kurikulum dipaparkan pada Tabel 4. Hasil dari pengisian angket oleh siswa dipaparkan pada Tabel 5 .

\section{Tabel 2. Hasil Wawancara Mengenai Bahan Ajar}

\begin{tabular}{|c|c|}
\hline No. Topik Pertanyaan & Jawaban \\
\hline $\begin{array}{l}\text { 1. Ketersediaan } \\
\text { bahan ajar }\end{array}$ & $\begin{array}{l}\text { Bahan ajar yang tersedia meliputi buku tematik terpadu dari pemerintah, buku } \\
\text { pendamping berisi rangkuman materi hasil Kelompok Kerja Guru (KKG), } \\
\text { media pembelajaran seperti KIT IPA, torso organ-organ manusia, poster } \\
\text { kebudayaan daerah, dan media penunjang lainnya seperti papan tulis, LCD } \\
\text { proyektor, dan perangkat komputer. }\end{array}$ \\
\hline $\begin{array}{l}\text { 2. Intensitas } \\
\text { penggunaan } \\
\text { bahan ajar }\end{array}$ & $\begin{array}{l}\text { Bahan ajar yang digunakan secara continuehanya buku tematik terpadu. } \\
\text { Tambahan media yang paling sering digunakan adalah media untuk } \\
\text { muatan IPA. Selebihnya guru hanya memanfaatkan media papan tulis dan } \\
\text { LCD proyektor untuk menampilkan tambahan materi pembelajaran. }\end{array}$ \\
\hline $\begin{array}{l}\text { 3. Permasalahan } \\
\text { mengenai bahan } \\
\text { ajar }\end{array}$ & $\begin{array}{l}\text { Bahan ajar yang dapat digunakan langsung oleh masing-masing siswa dengan } \\
\text { maksimal hanya buku tematik terpadu. Pembelajaran terkadang tidak bervari- } \\
\text { asi jika hanya mengandalkan bahan ajar yang ada saja. Sebenarnya, terdapat } \\
\text { buku pendamping tetapi hanya menjadi pegangan guru saja. }\end{array}$ \\
\hline $\begin{array}{l}\text { 4. Harapan pengem- } \\
\text { bangan bahan ajar }\end{array}$ & $\begin{array}{l}\text { Bahan ajar menjadi lebih lengkap dan menunjang pembelajaran yang variatif } \\
\text { sehingga siswa semakin termotivasi untuk belajar. }\end{array}$ \\
\hline $\begin{array}{l}\text { 5. Elemen yang di- } \\
\text { inginkan sebagai } \\
\text { kelengkapan } \\
\text { bahan ajar }\end{array}$ & $\begin{array}{l}\text { Bahan ajar sebaiknya terdiri dari pedoman penggunaannya, informasi keter- } \\
\text { kaitan dengan } \mathrm{KD} \text {, penguatan materi, gambar penunjang, soal evaluasi, dan } \\
\text { pedoman kegiatan siswa. }\end{array}$ \\
\hline
\end{tabular}




\section{Tabel 3. Hasil Wawancara Mengenai Karakteristik Siswa}

\begin{tabular}{|c|c|}
\hline No. Topik Pertanyaan & Jawaban \\
\hline 1. Jumlah siswa & Siswa kelas V terdiri dari satu rombel dengan jumlah 29 siswa. \\
\hline 2. Hasil be & $\begin{array}{l}\text { Hasil belajar siswa rata-rata sudah cukup baik. Namaun ada satu siswa } \\
\text { yag tempo belajarnya cukup lambat dibandingkan lainnya. }\end{array}$ \\
\hline 3. Minat belajar siswa & $\begin{array}{l}\text { Minat belajar siswa sangat tergantung dengan kegiatan pembelajaran } \\
\text { yang sedang dilaksanakan. Jika kegiatannya menyenangkan, siswa minat } \\
\text { belajarnya tinggi. Ada beberapa siswa yang kurang memiliki minat dan } \\
\text { motivasi belajar. }\end{array}$ \\
\hline $\begin{array}{l}\text { 4. Permasalahan yang } \\
\text { sering muncul }\end{array}$ & $\begin{array}{l}\text { Persiapan pembelajaran harus sangat baik agar siswa semangat belajar. } \\
\text { Siswa sangat mudah jenuh saat pembelajaran. Belum semua penguatan } \\
\text { karakter dapat membudaya pada diri siswa. }\end{array}$ \\
\hline 5. Harapan k & $\begin{array}{l}\text { Banyak bahan ajar yang dapat menunjang pembelajaran lebih lengkap } \\
\text { dan bervariatif. Hal ini bertujuan agar siswa lebih semangat lagi dalam } \\
\text { belajar. }\end{array}$ \\
\hline
\end{tabular}

\section{Tabel 4. Hasil Wawancara Mengenai Kurikulum yang Digunakan}

\begin{tabular}{|c|c|c|}
\hline No. & Topik Pertanyaan & Jawaban \\
\hline 1. & $\begin{array}{l}\text { Kurikulum yang } \\
\text { diterapkan }\end{array}$ & $\begin{array}{l}\text { Kurikulum yang diterapkan adalah kurikulum 2013. Siswa belajar seca- } \\
\text { ra full day school, jadi hanya } 5 \text { hari belajar. Pembelajarannya menerpa- } \\
\text { kan pembelajaran tematik terpadu. }\end{array}$ \\
\hline 2. & $\begin{array}{l}\text { Metode pembelajaran } \\
\text { yang sering diterapkan }\end{array}$ & $\begin{array}{l}\text { Metode yang paling sering diterapkan adalah metode diskusi kelompok } \\
\text { dan penugasan secara kelompok. Pembelajaran saat ini sudah mulai } \\
\text { meminimalisir ceramah. }\end{array}$ \\
\hline 3. & $\begin{array}{l}\text { Permasalahan menge- } \\
\text { nai kurikulum pembe- } \\
\text { lajaran }\end{array}$ & $\begin{array}{l}\text { Perlu pembelajaran yang sangat bervariatif tetapi sering terhalang tu- } \\
\text { gas di luar pembelajaran yang menyebabkan siswa sering belajar sen- } \\
\text { diri tanpa dampingan guru. Sehingga hasilnya kurang maksimal dan } \\
\text { masih terdapat materi yang belum dipahami oleh siswa. }\end{array}$ \\
\hline 4. & $\begin{array}{l}\text { Muatan atau tema yang } \\
\text { membutuhkan pengem- } \\
\text { bangan bahan ajar }\end{array}$ & $\begin{array}{l}\text { Secara keseluruhan sebenarnya prestasi siswa menunjukkan tidak ada } \\
\text { tema yang terlalu menonjol ataupun jauh di bawah. Tetapi pembelajar- } \\
\text { an tema } 5 \text { "ekosistem" masih perlu adanya pengembangan bahan ajar. } \\
\text { Mengingat tema ini berdekatan dengan pelaksanaan UAS sehingga } \\
\text { siswa lebih sering belajar sendiri tanpa didampingi guru kelas. }\end{array}$ \\
\hline
\end{tabular}

Tabel 5. Hasil Angket Analisis Kebutuhan

\begin{tabular}{|c|c|c|c|c|}
\hline Indikator & Nilai & $\begin{array}{l}\text { Persentase } \\
(\%)\end{array}$ & $\begin{array}{l}\text { Rata-rata } \\
\text { Persentase }\end{array}$ & $\begin{array}{l}\text { Kategori } \\
\text { Tingkat } \\
\text { Kebutuhan }\end{array}$ \\
\hline $\begin{array}{l}\text { 1. Muatan pembelajaran yang membutuhkan } \\
\text { adalah tema ekosistem }\end{array}$ & 90 & 77,6 & \multirow{5}{*}{$83,12 \%$} & \multirow{5}{*}{$\begin{array}{l}\text { Sebagian besar } \\
\text { membutuhkan }\end{array}$} \\
\hline $\begin{array}{l}\text { 2. Jenis bahan ajarnya berupa buku pedoman } \\
\text { dilengkapi media }\end{array}$ & 121 & 83,4 & & \\
\hline 3. Bahan ajar berbasis game based learning & 149 & 85,6 & & \\
\hline 4. Bahan ajar bermuatan karakter kreatif & 88 & 75,9 & & \\
\hline $\begin{array}{l}\text { 5. Elemen yang dibutuhkan meliputi kaitan de- } \\
\text { ngan KD, gambar, penguatan materi, dan } \\
\text { tampilan penuh warna }\end{array}$ & 54 & 93,1 & & \\
\hline
\end{tabular}

Hasil tersebut menunjukkan bahwa rata-rata persentase mencapai $83,12 \%$. Apabila diinterpretasikan sesuai dengan Tabel 1, maka termasuk ke dalam rentang persentase $76 \%-99,9 \%$ dan masuk dalam kategori sebagian besar membutuhkan. 
Hasil pengisian angket analisis kebutuhan didukung pula dengan saran dan komentar dari siswa. Saran dan komentar siswa mengenai kebutuhan bahan ajar di pa- parkan pada Tabel 6. Hasil saran dan komentar dari siswa juga menjadi pertimbangan penentuan pengembangan bahan ajar yang harus dilakukan.

\section{Tabel 6. Saran dan Komentar Siswa Mengenai Kebutuhan Bahan Ajar}

\begin{aligned} & \hline No. \multicolumn{1}{c}{ Komentar dan Saran } \\ & \hline 1. $34 \%$ siswa menyarankan untuk mengembangkan bahan ajar yang penuh warna \\ & 2. Bahan ajar sebaiknya memuat pembelajaran yang lebih menarik dari buku tematik \\ & 3. Bahan ajar dilengkapi dengan video pembelajaran \\ & 4. Bahan ajar membantu siswa untuk berlatih menulis dan membaca \\ & 5. Bahan ajar dilengkapi gambar-gambar alam dan sesuai dengan materi \\ & 6. Bahan ajar dilengkapi kata-kata bijak atau kata motivasi \\ & 7. Bahan ajar dilengkapi dengan petunjuk kegiatan atau percobaan \\ & 8. Bahan ajar dilengkapi gambar animasi yang menarik \\ & \hline\end{aligned}

Hasil observasi diperoleh setelah observer mengikuti pembelajaran selama satu kali pembelajaran. Observer mengikuti pembelajaran mulai dari kegiatan pendahuluan hingga kegiatan akhir. Hasil observasi ini dapat menunjukkan kegiatan pembelajaran dari sudut pandang selain guru dan siswa itu sendiri. Dengan demikian, diharapkan data analisis kebutuhan dapat lebih lengkap dan tepat sasaran dilihat dari berbagai sudut pandang.
Hasil observasi menunjukkan bahwa proses pembelajaran masih dalam proses menuju PAIKEM. Bahan ajar yang digunakan secara intensif hanya berupa buku tematik terpadu. Selain itu, guru hanya menggunakan media-media yang mudah dijangkau oleh guru, misalnya LCD dan perangkat komputer untuk menampilkan gambar atau video pembelajaran. Selebihnya penggunaan bahan ajar lainnya sangat jarang. Hasil observasi secara keseluruhan dipaparkan pada Tabel 7.

\section{Tabel 7. Hasil Observasi Pembelajaran}

\begin{tabular}{ll}
\hline No. Aspek yang Dinilai & \multicolumn{1}{c}{ Keterangan } \\
\hline $\begin{array}{l}\text { 1. Situasi Pelaksanaan } \\
\text { Pembelajaran }\end{array}$ & $\begin{array}{l}\text { Siswa antusias pada awal pembelajaran. di pertengahan siswa su- } \\
\text { dah mulai tidak kondusif, tetapi beberapa kali guru mengingatkan } \\
\text { dan memusatkan kembali perhatian siswa. }\end{array}$ \\
$\begin{array}{ll}\text { 2. Proses Kegiatan } \\
\text { Pembelajaran } \\
\text { a. Kegiatan Pendahuluan }\end{array}$ & $\begin{array}{l}\text { Kegiatan awal seperti menyanyikan lagu nasional, berdoa, meng- } \\
\text { ucap janji siswa dan rutinitas pagi lainnyadilakukan secara ber- }\end{array}$ \\
& $\begin{array}{l}\text { samaan oleh seluruh warga sekolah di pagi hari. } \\
\text { Siswa merapikan dan membersihkan lingungan kelas tempat } \\
\text { mereka belajar sesuai dengan arahan guru. }\end{array}$ \\
& $\begin{array}{l}\text { Guru menyampaikan apersepsi, tujuan pembelajaran, dan topik } \\
\text { materi yang akan dipelajari. }\end{array}$ \\
& Siswa melakukan kegiatan pembelajaran berdasarkan buku tematik \\
terpadu. & Siswa menyimak video pembelajaran yang ditayangkan oleh guru. \\
& Siswa melakukan kegiatan pembelajaran dan penugasan dengan \\
& metode diskusi kelompok. \\
& Siswa mengerjakan soal evaluasi yang diberikan guru.
\end{tabular}




\begin{tabular}{ll}
\hline No. Aspek yang Dinilai & \multicolumn{1}{c}{ Keterangan } \\
\hline c. Kegiatan Akhir & $\begin{array}{l}\text { Siswa membuat rangkuman dan bersama guru melakukan } \\
\text { perencanaan untuk kegiatan belajar selanjutnya. }\end{array}$ \\
$\begin{array}{l}\text { Siswa berdoa dan guru memberi salam penutup } \\
\text { 3. Bahan ajar yang digunakan } \\
\text { saat pembelajaran }\end{array}$ & $\begin{array}{l}\text { Guru memanfatkan buku tematik sebagai sumber belajar. Selain itu } \\
\text { guru menggunakan LCD proyektor untuk menampilkan video dan } \\
\text { gambar. }\end{array}$ \\
4. Catatan temuan saat pem- \\
belajaran
\end{tabular}

\section{Pembahasan}

Pembahasan dibagi menjadi 3 bagain sesuai dengan teknik pengumpulan data yang dilakukan yakni melalui wawancara, angket analisis kebutuhan, dan observasi.

\section{Wawancara}

Mengacu berdasar hasil penelitian, dari sudut pandang guru menunjukkan adanya kebutuhan bahan ajar yang lebih lengkap dan bervariatif. Mengenai bahan ajar dan ketersediannya pada pembelajaran, guru mengungkapkan bahwa bahan ajar yang tersedia di sekolah meliputi buku tematik terpadu dari pemerintah, buku pendamping berisi rangkuman materi hasil KKG, media pembelajaran seperti KIT IPA, torso organorgan manusia, poster kebudayaan daerah, dan media penunjang lainnya seperti papan tulis, LCD proyektor, dan perangkat komputer. Meskipun bahan ajar cukup banyak tetapi bahan ajar yang intensif digunakan hanya buku tematik terpadu dan media pembelajaran untuk muatan IPA saja.

Permasalahan yang paling sering muncul mengenai bahan ajar adalah tidak tersedianya bahan ajar yang menunjang pembelajaran untuk lebih bervariasi. Hal ini yang menyebabkan siswa mudah bosan jika guru tidak pandai mengelola kelas. Bahan ajar yang dapat merata digunakan oleh siswa hanya buku tematik terpadu. Guru menilai buku tematik kurang menunjang pembelajaran apabila tidak didukung dengan pen- dalaman materi dan bimbingan guru.

Guru berharap akan adanya pengembangan bahan ajar yang lebih lengkap dan variatif agar siswa lebih termotivasi untuk belajar. Elemen-elemen untuk melengkapi bahan ajar sebaiknya terdiri dari pedoman penggunaannya, informasi keterkaitan dengan KD, penguatan materi, gambar penunjang, soal evaluasi, dan pedoman kegiatan siswa. Dengan demikian, memang diperlukan adanya pengembangan bahan ajar. Mengingat pentingnya peran bahan ajar yang ditinjau dari pengertian bahan ajar itu sendiri. Menurut Nugraha, Binadja, \& Supartono (2013:28), bahan ajar merupakan semua jenis bahan yang digunakan untuk membantu guru dalam melaksanakan kegiatan belajar mengajar di kelas. Apabila guru menemui permasalahan mengai bahan ajar, tentu proses pembelajaran tidak dapat berlangsung secara optimal.

Mengenai karakteristiksiswa, guru banyak mengungkapkan bahwa siswa sebenarnya sudah memiliki kemampuan yang cukup baik. Hanya saja motivasi belajar siswa yang bisa menurun sewaktu-waktu apabila pembelajaran tidak menyenangkan. Guru juga mengungkapkan terdapat satu siswa yang sangat kurang motivasi belajarnya walaupun teman-temannya yang lain dapat mengikuti pembelajaran dengan baik. Terkadang guru menambahkan waktu khusus untuk siswa tersebut agar tidak tertinggal oleh temannya yang lain. Tetapi dengan 
penambahan waktu pun tidak dapat meningkatkan motivasi belajaranya.

Pengembangan bahan ajar yang dilakukan harus benar-benar dapat memfasilitasi karakter yang berbeda-beda tersebut. Sesuai dengan hasil penelitian Bintartik, Yuniawatika, \& Untari (2017:104-105) dapat diketahui bahwa gaya belajar siswa kelas V di SD Kota Blitar cukup bervariasi. Bahan ajar harus dapat memfasilitasi siswa yang gaya belajarnya auditorial, visual, maupun kinestetik agar keseluruhan siswa dapat belajar dengan baik.

Salah satu pemilihan jenis bahan ajar yang dapat memfasilitasi seluruh gaya belajar siswa adalah bahan ajar yang memuat games edukasi. Bahan ajar ini dapat diiplementasikan dengan game based learning. Guru menyetujui diperlukannya bahan ajar yang berbasis game based learning.

Guru juga mengungkapkan bahwa penguatan karakter belum sepenuhnya membudaya pada diri siswa. Pendidikan karakter ini dapat disesuaikan dengan bahan ajar yang ingin dikembangkan. Apabila pengembangan bahan ajarnya berbasis game based learning, karakter yang dapat diintegrasikan adalah karakter kreatif. Karakter kreatif erat hubungannya dengan syarat bahan ajar game based learning menurut Blessinger dan Wankel (Hidayat, 2018) yang menyatakan bahan ajar harus memenuhi karakteristik antara lain ada tantangan dan penyesuaian, ada tujuan yang diraih, memerlukan keahlian sosial dan kerja sama, menarik dan menggembirakan, adanya assesment, interaktif, adanya umpan balik, dan adanya keterampilan pemecahan masalah.

Mengenai kurikulum yang digunakan, guru mengungkapkan bahwa SDN Bendogerit 2 Kota Blitar sudah menerapkan Kurikulum 2013 dan sistem belajarnya full day school. Guru sering menerapkan metode diskusi kelompok untuk meminimalisir ceramah. Permasalahan yang paling sering ditemui guru adalah terpotongnya jam mengajar guru dengan tugas-tugas di luar pembelajaran. Tema yang paling mendapat dampak adalah tema ekosistem. Tema ini berdekatan dengan UAS semester 1 sehingga siswa sering belajar tanpa didampingi guru. Dampaknya cukup banyak materi yang belum dipahami siswa dengan baik.

\section{Angket Analisis Kebutuhan}

Angket analisis kebutuhan diisi oleh 29 siswa kelas V SDN Bendogerit 2 Kota Blitar tahun pelajaran 2019/2020. Angket yang menggunakan skala Guttman ini memiliki total 21 pertanyaan dengan dilengkapi kolom komentar dan saran. Dari pengisian angket analisis kebutuhan diperoleh temuan seperti yang terlihat pada Gambar 1 .

\section{Muatan atau tema yang membutuhkan ba- han ajar adalah tema ekosistem}

Berdasarkan pengalaman siswa yang harus banyak belajar sendiri menjelang UAS mengakibatkan banyak siswa yang setuju bahwa pengembangan bahan ajar sebaiknya diperuntukkan tema ekosistem. Tema ekosistem merupakan tema ke-5 dan terakhir pada semester 1 . Guru banyak mendapat tugas di luar pembelajaran sehingga siswa sering belajar tanpa didampingi guru.

Pengembangan bahan ajar yang memuat sebuah tema sudah sesuai dengan penerapan Kurikulum 2013. Karitas (2017), dalam mengembangkan tiga kompetensi dasar siswa pada kurikulum 2013 yang terdiri dari ranah pengetahuan, sikap, dan keterampilan dapat dilakukan dengan memadukan ketiga ranah tersebut melalui penerapan pembelajaran tematik terpadu. 


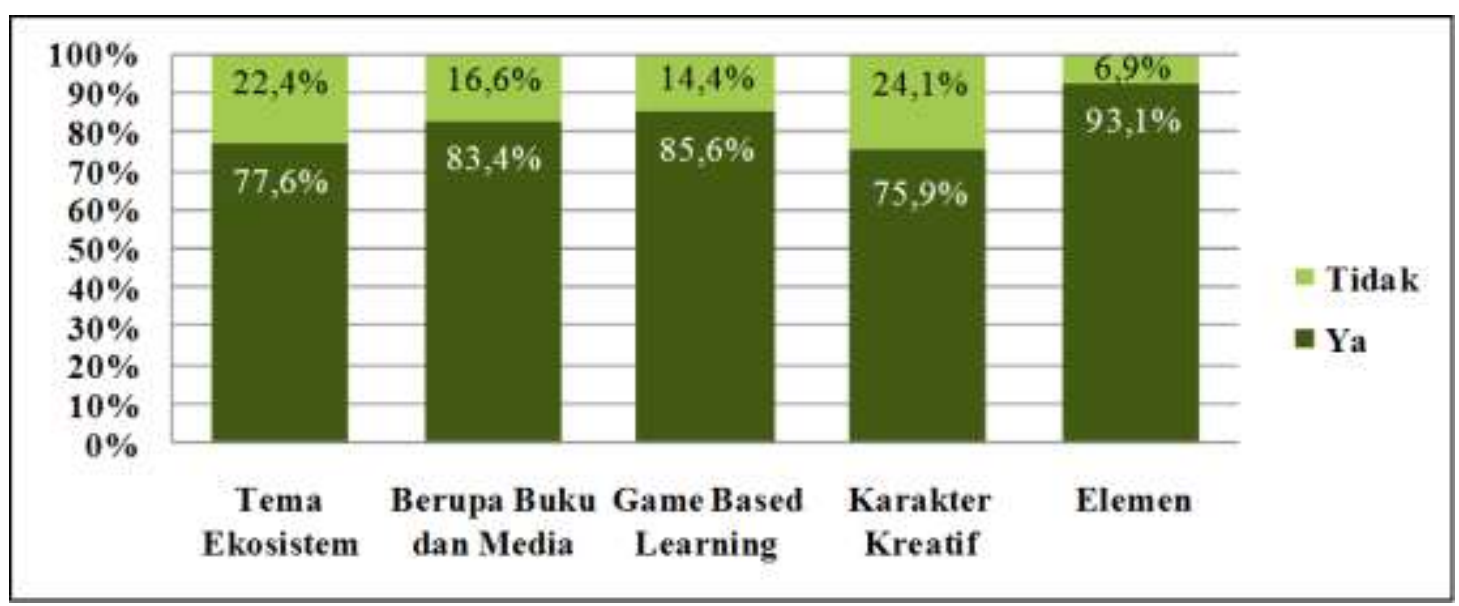

Gambar 1. Hasil Angket Analisis Kebutuhan

Terdapat 4 butir pertanyaan pada angket yang menanyakan mengenai muatan atau tema yang membutuhkan pengembangan bahan ajar. Hasil nya terdapat 90 jawaban "ya" pada tema ekosistem dan 26 jawaban "tidak". Dari hasil ini diperoleh persentase yang mengemukakan setuju mengenai pengembangan bahan ajar pada tema ekosistem mencapai 77,6\%. Berdasarkan kategorisasi oleh Munggaran (2012), hasil ini masuk kategori sebagian besar membutuhkan. Artinya sebagian besar siswa kelas $\mathrm{V}$ membutuhkan bahan ajar untuk tema ekosistem.

\section{Jenis bahan ajar yang dibutuhkan berupa buku dan media}

Jenis bahan ajar yang terdapat di SDN Bendogerit 2 Kota Blitar sudah cukup beragam. Tetapi pemanfatannya masih kurang. Bahan ajar yang sering digunakan hanya berupa buku tematik terpadu.

Pada angket analisis kebutuhan terdapat 5 pertanyaan yang berhubungan dengan jenis bahan ajar yang dibutuhkan oleh siswa. Hasilnya terdapat 121 jawaban "ya" untuk bahan ajar berupa buku dengan media dan 24 jawaban "tidak". Hasil ini menunjukkan bahwa $83,4 \%$ siswa setuju akan adanya pengembangan bahan ajar berupa buku dilengkapi dengan medianya. Berdasarkan kategorisasi oleh Munggaran (2012), hasil ini termasuk kategori sebagian besar siswa membutuhkan. Artinya sebagian besar siswa kelas $\mathrm{V}$ membutuhkan bahan ajar berupa buku yang dilengkapi dengan media pembelajaran.

Buku termasuk jenis bahan ajar visual. Sedangkan media dalam pandangan Tocharman (Nugraha, Binadja, \& Supartono, 2013) dapat berupa jenis bahan ajar yang beragam. Jenis-jenis bahan ajar meliputi bahan ajar visual, audio, audio visual, dan interactive teaching material. Media dapat dikembangkan menjadi keempat jenis bahan ajar tersebut. Dengan bahan ajar yang beragam tentu pembelajaran akan lebih bervariatif.

\section{Bahan ajar yang dibutuhkan berbasis game based learning}

Beragamnya karakter dan gaya belajar siswa membuat siswa menyukai pembelajaran yang cenderung bersifat menyenangkan dan dapat memfasilitasi semua karakteristik siswa. Siswa memiliki pendapat yang beragam mengenai model pembelajaran yang mereka sukai. Karena kagiatan pembelajaran sering didominasi dengan kegiatan berkelompok, siswa menyukai kegiatan berkelompok.

Pada angket terdapat 6 butir pertanyaan yang diajukan kepada siswa mengenai model yang dapat diimplementasikan pada 
bahan ajar. Hasilnya terdapat 149 jawaban "ya" yang memilih model game based learning dan 25 jawaban "tidak". Hasil persentasenya mencapai 85,6\% siswa menyetujui bahan ajar yang berbasis game based learning. Merujuk pada kategorisasi oleh Munggaran (2012), hasil ini termasuk kategori sebagian besar siswa membutuhkan. Artinya, sebagian besar siswa kelas $\mathrm{V}$ membutuhkan bahan ajar berbasis game based learning.

Hasil pemilihan siswa menunjukkan bahwa siswa menyenangi bahan ajar berbasis game based learning. Hal ini sejalan dengan hasil analisis kebutuhan yang dilakukan oleh Waldopo (2011:252) yang menunjukkan hasil bahwa format yang paling disenangi siswa dan guru dalam media pembelajarannya adalah games dan tutorial.

Pemilihan bahan ajar berbasis game based learning didukung pula dengan keberhasilan berbagai penelitian terdahulu. Berdasarkan hasil penelitian yang dilakukan oleh Ratminingsih (2018) dapat diketahui bahwa pembelajaran yang memanfaatkan games dapat membuat siswa bersemangat untuk berpartisipasi aktif dan tertantang untuk mampu memahami permasalahan dalam games. Selain itu, hasil penelitian Wang, Shang, \& Briody (2011) menunjukkan bahwa penggunaan games dan motivasi belajar siswa memiliki hubungan positif dan signifikan.

\section{Bahan ajar diintegrasikan dengan karakter kreatif}

Pendidikan karakter merupakan salah satu penekanan pada implementasi Kurikulum 2013. Penguatan karakter sangat tepat apabila diintegrasikan dalam bahan ajar. Dengan demikian, diharapkansecara tidak langsung karakter dapat membudaya pada diri siswa.

Pada angket analisis kebutuhan terdapat 4 butir pertanyaan mengenai pengintegrasian karakter dalam bahan ajar. Hasilnya terdapat 88 jawaban "ya" yang memilih karakter kreatif dan 28 jawaban "tidak". Persentasenya mencapai $75,9 \%$ siswa yang menyetujui pengintegrasian karakter kreatif pada bahan ajar. Merujuk pada kategorisasi oleh Munggaran (2012), hasil ini termasuk kategori lebih dari setengahnya membutuhkan. Dapat disimpulkan bahwa dibutuhkan pengembangan bahan ajaryang terintegrasi penguatan karakter kreatif karena terdapat lebih dari setengah dari siswa yang membutuhkan.

Pengintegrasian karakter kreatif tepat dilakukan bahan ajar yang menerapkan game based learning. Menurut Daeng (Ismail, 2009: 17) bermain merupakan kegiatan yang dilakukan dalam setiap kehidupan anak dan menjadi bagian integral dari proses penguatan kepribadiannya. Dengan demikian, gamebased learning dapat lebih dihayati oleh siswa sekaligus sebagai upaya pembentukan karakter kreatif pada siswa.

\section{Elemen yang dibutuhkan pada bahan ajar meliputi identitas yang berkaitan dengan KD, gambar, penguatan materi, dan tam- pilan penuh warna}

Angket analisis kebutuhan mempunyai 2 pertanyaan mengenai elemen apa saja yang dibutuhkan dalam bahan ajar. Hasilnya terdapat 54 jawaban "ya" yang menyetujui elemen-elemen meliputi identitas yang berkaitan dengan $\mathrm{KD}$, gambar, penguatan materi, dan tampilan yang penuh warna dan terdapat 4 jawaban "tidak".

Persentase jawaban siswa yang menyetujui elemen-elemen pelengkap bahan ajar mencapai 93,1\%. Berdasarkan kategorisasi oleh Munggaran (2012), hasil ini termasuk dalam kategori sebagian besar siswa membutuhkan. Dengan demikian, dapat disimpulkan bahwa siswa membutuhkan bahan ajar yang dilengkapi dengan identitas yang berkaitan dengan KD, gambar, penguatan materi, dan tampilan yang penuh warna. 
Hasil pengisisan angket mengenai elemen-elemen bahan ajar ini sudah sesuai dengan beberapa elemen yang baik untuk bahan ajar. Bahan ajar yang baik menurut Hernawan, Permasih, \& Dewi (2012) harus mencakup tujuan pembelajaran, kompetensi dasar, materi pembelajaran, ilustrasi media, prosedur pembelajaran, latihan dilengkapi dengan petunjuk jawaban, umpan balik, daftar pustaka.

\section{Saran dan komentar siswa}

Angket analisis kebutuhan juga dilengkapi dengan kolom saran dan komentar. Siswa diperbolehkan menuliskan saran dan komentar mereka mengenai kebutuhan pengembangan bahan ajar. Pengisisan saran dan komentar tidak dibatasi pada topik tertentu. Siswa bahkan diperbolehkan menuliskan permasalahan dan keinginannya saat pembelajaran.

Hasil dari saran dan komentar siswa meliputi hal-hal berikut. Sepertiga siswa atau $34 \%$ siswa menyarankan untuk mengembangkan bahan ajar yang penuh warna. Siswa yang lain menginginkan warna yang sangat bervariasi sesuai dengan kesenangan tiap individunya.

Terdapat saran yang menunjukkan bahwa siswa menginginkan buku pembelajaran yang lebih menarik dari buku tematik. Selain itu, siswa meminta untuk melengkapi buku dengan kegitan literasi dan peningkatan baca tulis.

Saran dan komentar selebihnya mengungkapkan tentang keinginan siswa untuk memiliki bahan ajar yang sangat variatif. Siswa menginginkan bahan ajar untuk dilengkapi dengan video pembelajaran, gambargambar alam yang sesuai dengan materi, kata-kata bijak yang memotivasi belajar, petunjuk kegiatan atau percobaan, dan juga gambar animasi yang menarik.

\section{Observasi}

Observasi menghasilkan data kegiatan pembelajaran mulai dari pendahuluan sampai dengan kegiatan akhir. Kegiatan pendahuluan yang dilakukan siswa kelas V hampir sama dengan kegiatan siswa di SD pada umumnya.

Rutinitas pagi dilakukanbersama-sama dengan semua warga sekolah baru kemudia siswa masuk kedalam kelas. Guru banyak menerapkan kegiatan kelompok dan penugasan pada kegiatan inti. Pada kegiatan akhir siswa membuat rangkuman dan merefleksi kegiatannya selama sehari belajar di sekolah. Penggunaan bahan ajar masih didominasi dengan penggunaan buku tematik terpadu. Selain itu, guru mamanfaatkan LCD dan perangkat komputer untuk menampilkan video dan gambar pembelajaran. siswa cuku antusias ketiga menyimak video ataupun mengamati gambar dari layar proyeksi.

Temuan yang diperoleh dari hasil observasi meliputi hal-hal berikut. (1) Siswa lebih senang belajar dari video daripada menggunakan buku dan (2) siswa antusias saat guru memberikan icebreaking danmengajak siswa untuk bermain. Hal ini sesuai dengan temuan dari penelitian menurut Wang, Shang, \& Briody (2011) penggunaan games dan motivasi belajar siswa memiliki hubungan positif dan signifikan.

Dari uraian di atas dapat bahwa siswa memiliki motivasi belajar yang tinggi dengan pembelajaran yang sifatnya menyenangkan. Siswa membutuhkan bahan ajar yang menarik. Penentuan bahan ajar yang menerapkan game dapat menjadi pilihan untuk siswa. Hal ini tergambar saat siswa sangat antusias saat guru mengajak untuk bermain.

\section{SIMPULAN}

Tujuan dari penelitian ini adalah memperoleh informasi mengenai analisis kebu- 
tuhan tentang: (1) kebutuhan bahan ajar game based learning pada pembelajaran di kelas $\mathrm{V}$ SDN Bendogerit 2 Kota Blitar; (2) muatan atau tema pembelajaran yang memerlukan bahan ajar; (3) jenis bahan ajar yang dibutuhkan; (4) penguatan karakter yang terintegrasi dalam bahan ajar; dan (5) elemen yang terkandung di dalam bahan ajar tersebut.

Hasil wawancara dengan guru menunjukkan bahwa guru membutuhkan bahan ajar yang lebih lengkap dan bervariatif. Hasil pengisisan angket analisis kebutuhan oleh siswa menunjukkan secara kuantitatif ratarata persentase kebutuhan siswa mencapai $83,12 \%$, dengan rincian $77,6 \%$ siswa membutuhkan bahan ajar untuk tema ekosistem, $83,4 \%$ siswa membutuhkan bahan ajar berupa buku dan media, $85,6 \%$ siswa menyetujui bahan ajar game based learning, 75,9\% siswa menyetujui pengintegrasian karakter kreatif pada bahan ajar, dan 93,1\% mengemukakan elemen yang dibutuhkan untuk bahan ajar meliputi identitas berkaitan dengan KD, gambar, penguatan materi, dan tampilan penuh warna. Hasil saran dan komentar siswa menunjukkan siswa menginginkan bahan ajar dengan penuh warna, lebih menarik dari bahan ajar yang telah ada, dan dilengkapi dengan variasi lainnya. Hasil observasi menunjukkan siswa lebih senang belajar dari video daripada menggunakan buku dan siswa antusias saat guru memberikan ice breaking dan mengajak siswa untuk bermain.

Dibutuhkan bahan ajar game based learning yang terintegrasi dengan karakter kreatif. Bahan ajar ini diperuntukkan siswa dan guru kelas V SDN Bendogerit 2 Kota Blitar. Bahan ajar yang dibutuhkan berupa buku dan media pembelajaran yang bervariasi. Elemen-elemen yang dibutuhkan untuk kelengkapan bahan ajar meliputi pedoman penggunaannya, identitas dan keterkaitan- nya dengan $\mathrm{KD}$, penguatan materi, gambar penunjang, soal evaluasi, pedoman kegiatan siswa, dan tampilan yang penuh warna.

Diharapkan terdapat penelitian yang berkelanjutan mengenai pengembangan bahan ajar game based learning yang terintegrasi dengan karakter kreatif pada tema ekosistem untuk kelas V SDN Bendogerit 2 Kota Blitar. Bahan ajar yang dikembangkan diharapkan lebih lengkap, bervariatif, dan lebih menarik dari bahan ajar yang sudah ada. Diharapkan pula guru mampu memanfaatkan semua bahan ajar yang telah ada maupun yang akan dikembangkan dengan sebaik mungkin agar dapat meningkatkan motivasi belajar siswa.

\section{UCAPAN TERIMA KASIH}

Puji syukur atas rahmat yang dilimpahkan oleh Tuhan Yang Maha Esa sehingga penulis dapat menyelesaikan penulisan artikel ini. Terima kasih disampaikan kepada pihak PNBP Universitas Negeri Malang sebagai pendonor dana penelitian. Terima kasih kepada pihak SDN Bendogerit 2 Kota Blitar sebagai subjek dari penelitian ini. Terlebih penulis mengucapkan terima kasih kepada Dewan Redaksi Jurnal Pendidikan Karakter yang telah menelaah draf artikel ini hingga layak dimuat dan dibaca.

\section{DAFTAR PUSTAKA}

Bintartik, L., Yuniawatika, \& Untari, E. (2017). Learning style of grade V students at elementary schools in Blitar. International Research-Based Education Journal, 1(2), 103-107. DOI: http://dx.doi.org/10.17977/um043v1i2p103107.

Bire, A.L., Geradus, U., \& Bire, J. (2014). Pengaruh gaya belajar visual, auditorial, dan kinestetik terhadap prestasi belajar siswa. Jurnal Kependidikan: Pene- 
litian Inovasi Pembelajaran, 44(2), 168174. DOI: https://doi.org/10.21831/jk.v44i2.5307.

Davidson, M. (2014). A character education research perpective for 21st century. Journal of Character Education. 10(1), 77-83. Retrieved from http://www.infoagepub.com/journal-of-charactereducation.

Hernawan, A.H., Permasih, \& Dewi, L. (2012). Pengembangan bahan ajar. In Direktorat UPI. Bandung: UPI.

Hidayat, R. (2018). Game-based learning: Academic games sebagai metode penunjang pembelajaran kewirausahaan. Bulletin Psikologi, 26(2), 71-85. DOI: 10.22146/buletinpsikologi.30988

Ismail, A. (2009). Education games: Panduan praktis permainan yang menjadikan anak anda cerdas, kreatif, dan saleh. Yogyakarta: Pilar Media.

Karitas, D.P. (2017). Buku tematik terpadu kurikulum 2013 tema 5: Ekosistem untuk siswa SD/MI Kelas V (B. Maftuh, D. Susilowati, K. A. Sugeng, Mu'arifin, W.S. Hastuti, N.W. Rochmadi, Suparwoto, A. Sastromiharjo, S. Zebua, \& T.T.H. Retnowati (eds.); Revisi 2017). Jakarta: Pusat Kurikulum dan Perbukuan, Balitbang, Kemendikbud.

Kemendikbud. (2017). Permendikbud No. 22 Tahun 2016 tentang Standar Proses Pendidikan Dasar dan Menengah. Jakarta: Kemendikbud.

Kemendikbud. (2018). Permendikbud Nomor 20 Tahun 2018 Tentang Penguatan Pendidikan Karakter pada Satuan Pendidikan
Formal. Jakarta: Kemendikbud.

Maulidina, M.A., Susilaningsih, S., \& Abidin, Z. (2018). Pengembangan game based learning berbasis pendekatan saintifik pada siswa kelas IV sekolah dasar. Jurnal Inovasi dan Teknologi Pembelajaran, 4(2), 113-118. DOI: http://dx.doi.org/10.17977/um031v4i2201 8p113.

Munggaran, R.D. (2012). Pemanfaatan open source software pendidikan oleh mahasiswa dalam rangka implementasi UndangUndang No. 19 Tahun 2002 Tentang Hak Cipta. Bandung: Universitas Pendidikan Indonesia.

Nugraha, D., Binadja, A., \&Supartono(2013). Pengembangan bahan ajar reaksi redoks bervisi SETS, berorientasi konstruktivistik. Journal of Innovative Science Education, 2(1), 28-34. Retrieved from https://journal.unnes.ac.id/sju/index.php/jise/article/view/128 9.

Putri, N.A. (2011). Penanaman nilai-nilai pendidikan karakter melalui mata pelajaran sosiologi. Jurnal Komunitas, 3(2), 201-215. Retrieved from http://journal.unnes.ac.id/nju/index.php/k omunitas/article/download/2317/2 370.

Qodriyah, S. \& Wangid, M.N. (2015). Pengembangan SSP tematik integratif untuk membangun karakter kejujuran dan kepedulian siswa SD kelas II. Jurnal Prima Edukasia, 3(2), 177-189. DOI: https://doi.org/10.21831/jpe.v 3i2.7222. 
Rahayuningtyas, D. I., \& Mustadi, Ali. 2018. Analisis muatan nilai karakter pada buku ajar kurikulum 2013 pegangan guru dan siswa Sekolah Dasar. Jurnal Pendidikan Karakter, 8(2), 123-139. DOI: https:// doi.org/10.21831/jpk.v8i2.21 848.

Ratminingsih, N.M. (2018). Implementasi board games dan pengaruhnya terhadap hasil belajar bahasa Inggris. Jurnal Ilmu Pendidikan, 24(1), 19-28. DOI: http://dx.doi.org/10.17977/um048v 24i1p19-28.
Waldopo. (2011). Analisis kebutuhan terhadap program multi media interaktif sebagai media pembelajaran. Jurnal Pendidikan Dan Kebudayaan, 17(2), 244253. DOI: http://dx.doi.org/10.24832/jpnk.v17i2.21.

Wang, Y.J., Shang, H.F., \& Briody, P. (2011). Investigating the impact of using games in teaching children English. International Journal of Learning $\mathcal{E}$ Development, 1(1), 127-141. DOI: http://dx.doi.org/10.5296/ijld.v1i1.1118. 